\title{
Lung function abnormalities at 6 months of age after neonatal intensive care
}

\author{
B Yuksel, A Greenough, S Green
}

\begin{abstract}
Respiratory function was studied in 46 preterm infants (median gestational age 28 weeks) at 6 months of age. Respiratory function was assessed by measurement of thoracic gas volume, airways resistance (from which specific conductance was calculated), and functional residual capacity. To determine the effect of the duration of neonatal intermittent positive pressure ventilation (IPPV) on respiratory function, the infants' results were divided into three groups: group A, no IPPV; group B, IPPV for less than seven days; and group C, IPPV for more than seven days. Measurements of thoracic gas volume and functional residual capacity were similar to published reference ranges and there were no significant differences between the three groups. Measurements of airways resistance and specific conductance were higher than published reference ranges (mean airways resistance of group A, $34 \mathrm{~cm} \mathrm{H} \mathrm{H}_{2} \mathrm{O} / 1 / \mathrm{sec} ; \mathrm{B}$, $34 \cdot 1 \mathrm{~cm} \mathrm{H} / \mathrm{O} / 1 / \mathrm{sec}$, and $\mathrm{C}, 30.4 \mathrm{~cm} \mathrm{H}$ O/1/sec) but there was no significant difference between the three groups. The $95 \%$ confidence intervals of the difference of the means between groups A and B were -6.94 to 6.73 $\mathrm{cm} \mathrm{H}_{2} \mathrm{O} / \mathrm{/} / \mathrm{sec}$ and between groups $A$ and $C$ -3.8 to $11.0 \mathrm{~cm} \mathrm{H}_{2} \mathrm{O} / 1 / \mathrm{sec}$. Our results suggest that factors other than neonatal ventilation may be more important in the pathogenesis of chronic lung function abnormalities in preterm infants.
\end{abstract}

Chronic lung damage is a frequent complication of preterm delivery. ${ }^{12}$ Such infants have a high mortality and morbidity, with an increased rehospitalisation rate and risk of respiratory infection. ${ }^{3}$ Many infants wheeze at follow up, ${ }^{3-5}$ and lung function abnormalites may be demonstrated during the first year of life. ${ }^{67}$

Several studies have suggested that positive pressure support is particularly important in the pathogenesis of chronic lung disease. ${ }^{8}$ Before 1969 bronchopulmonary dysplasia, the most severe form of chronic lung disease, was rarely seen, although spontaneously breathing infants were often exposed to $100 \%$ oxygen. After 1969 , however, bronchopulmonary dysplasia was seen and this coincided with the introduction of continuous positive airways pressure. ${ }^{9}$ Bronchopulmonary dysplasia was also described in ventilated infants who had required an oxygen concentration of less than $60 \%{ }^{10}$ The level of peak airway pressure used during mechanical ventilation seemed to be an important determinant of lung damage. Taghizadeh and Reynolds in 1976 reported a highly significant association between the most serious changes of bronchopulmonary dysplasia and use of peak inspiratory pressures in excess of $35 \mathrm{~cm} \mathrm{H} \mathrm{H}_{2} \mathrm{O} .{ }^{11}$ Moreover, the incidence of bronchopulmonary dysplasia was reduced by limiting the peak inspiratory pressure to $35 \mathrm{~cm} \mathrm{H}_{2} \mathrm{O}$; this change occurred despite inspired oxygen concentrations during ventilation that were often above $80 \%$. Stocks and Godfrey further incriminated positive pressure support by demonstrating lung function abnormalities at follow up among infants who had received artificial ventilation, but not among those who had been treated with other forms of respiratory support. ${ }^{12}$

The studies implicating positive pressure support in the pathogenesis of chronic lung damage were performed over a decade ago. At that time slow ventilator rates with long inspiratory times were employed during mechanical ventilation. High frequency positive pressure ventilation ${ }^{13}$ and patient triggered ventilation ${ }^{14}{ }^{15}$ are now more frequently used; both modes of ventilation incorporate short inspiratory times and fast frequencies. A further advance in neonatal ventilation over the 10 year period has been in improvements in the ventilators themselves. ${ }^{16}$ Changes in the ventilators and modes of neonatal ventilation may have reduced the damaging effect of positive pressure support.

In this study we have tested the hypothesis that, in 1990, neonatal ventilation is less important in the pathogenesis of chronic lung damage. As an index of chronic lung damage we have measured lung function at 6 months of age. To assess the effect of neonatal ventilation we have compared the lung function results of infants who required no neonatal ventilation with those who were ventilated and also between two groups of preterm infants who required different durations of neonatal ventilation. If our hypothesis is correct then we should expect similar lung function results between infants with and without neonatal ventilation and between infants ventilated for different durations.

\section{Patients and methods}

\section{PATIENTS}

Forty six preterm low birthweight infants were enrolled into the study and reviewed at 6 months of age (range 23-25 weeks). The infants had a median (range) birth weight of 1210 (5061900) $\mathrm{g}$ and median (range) gestational age of 28 (23-34) weeks. All the infants who had respiratory problems had suffered from respiratory 
distress syndrome. All but four of the infants had required some form of respiratory support either an increase in the inspired oxygen concentration or mechanical ventilation. Infants requiring mechanical ventilation had been ventilated at rates of between 60 and 120 breaths per minute and had an inspiratory to expiratory (I:E) ratio of $1: 1 \cdot 2$. Mechanical ventilation was started in the labour suite if the infant made inadequate respiratory efforts or during the course of the infant's illness if either a respiratory acidosis developed ( $\mathrm{pH}<7 \cdot 25$ ) or the infant had frequent minor or a major apnoea. Infants with severe bronchopulmonary dysplasia who were still oxygen dependent at 6 months of age were excluded from the study.

\section{Methods}

The infants were seen in the paediatric respiratory laboratory at 6 months of age. Their medical history was taken, height and weight measured, and the child examined. Lung mechanics, thoracic gas volume, airways resistance, and functional residual capacity were then measured after sedation. Specific conductance was calculated from thoracic gas volume and airways resistance. The infant was sedated with oral chloral hydrate $(100 \mathrm{mg} / \mathrm{kg})$ and lung mechanics measured during quiet sleep in the supine position.

Thoracic gas volume and airways resistance were measured using a whole body plethysmograph. The infant breathed through a face mask, which was connected to the rebreathing bag via a heated pneumotachograph and was sealed around the infant's nose and mouth using silicone putty to ensure an airtight seal. The infant breathed through a heated, humidified rebreathing system to avoid box pressure changes due to the heating and cooling of respired gas. Thoracic gas volume was measured at the end of a normal inspiration and airways resistance at two thirds of maximum inspiratory flow by the classical techniques of Dubois et al suitably modified for infants. ${ }^{17} 18$ Thoracic gas volume was calculated from five breaths during occlusion and at least five separate occlusions were made. Airways resistance was calculated from at least 10 breaths. All measurements (thoracic gas volume and airways resistance) were corrected for the apparatus dead space $(15 \mathrm{ml})$ and resistance $\left(8 \mathrm{~cm} \mathrm{H} \mathrm{H}_{2} \mathrm{O} / \mathrm{l}\right.$ $\mathrm{sec}$, measured at flows of between 5 and $15 \mathrm{~V}$ minute). Traces were analysed blind to clinical details.

After completion of the measurements of the thoracic gas volume and airways resistance the infant's face mask was connected to a spirometer (Gould Pulmonet III) for the measurement of functional residual capacity. The spirometer has an internal carbon dioxide absorber and an adjustable oxygen supply and has a total volume of six litres. The water sealed spirometer incorporates a digital display of functional residual capacity, which was recorded on the trace at $\mathbf{1 5}$ second intervals. Equilibration was assumed to have occurred when there had been no change in the functional residual capacity readout over a 30 second period; all the traces were coded and then analysed blind to clinical details. From the trace the equilibration point and expiratory level were determined and functional residual capacity calculated. The results were then converted to body temperature, pressure, and saturation (BTPS) conditions.

The reproducibility of the measurement of thoracic gas volume and airways resistance was determined in 16 children of similar gestational and postnatal age to the study population. Calculation of thoracic gas volume and airways resistance was as described above.

The coefficient of variation calculated from measurements of thoracic gas volume and airways resistance performed before and after infants had been removed and returned to the body plethysmograph was $6 \%$ for thoracic gas volume and $9 \%$ for airways resistance. To assess the reproducibility of the measurement of functional residual capacity, two separate measurements were made in 20 children of similar gestational and postnatal age to the study population. The coefficient of variation of these measurements was calculated as $7 \cdot 3 \%$.

\section{STATISTICAL ANALYSIS}

To assess the effect of ventilation and the duration of mechanical ventilation (IPPV) on lung function the infants were divided into three groups: no IPPV (group A), IPPV less than seven days (group B), and IPPV greater than seven days (group C). The clinical characteristics of the three groups are shown in table 1 . Lung function was then compared between the three groups and differences assessed for significance using the Wilcoxon rank sum test. The confidence intervals were calculated with the appropriate $p$ value from the standard error of the difference between the means of groups $A$ and $B$ and groups $A$ and $C$.

\section{TRIAL SIZE}

We had demonstrated the mean (SD) resistance of a previous group of 20 consecutive preterm infants studied at 6 months of age to be $35(7 \cdot 5)$ cm $\mathrm{H}_{2} \mathrm{O} / 1 / \mathrm{sec}$. Using these results, 12 patients would be required in each group to detect a difference in resistance of $10 \mathrm{~cm} \mathrm{H}_{2} \mathrm{O} / 1 / \mathrm{sec}$ between groups with $85 \%$ power at the $5 \%$ level.

Ethical permission for this study was granted by the King's College Hospital ethics committee.

\section{Results}

No significant difference in functional residual capacity, thoracic gas volume, specific conductance, or airways resistance was demonstrated

Table 1 Clinical characteristics of the three groups of infants divided according to the duration of ventilation. Results are median (range)

\begin{tabular}{lll}
\hline & $\begin{array}{l}\text { Birth weight } \\
(\mathrm{g})\end{array}$ & $\begin{array}{l}\text { Gestational age } \\
\text { (weeks) }\end{array}$ \\
\hline Group A $(\mathbf{n}=12)$ & $1386(1100-1800)$ & $29 \cdot 5(27-32)$ \\
Group B $(\mathbf{n}=22)$ & $1190(516-1900)$ & $29(25-34)$ \\
Group C $(\mathbf{n}=12)$ & $980(506-1512)$ & $27(23-32)$ \\
\hline
\end{tabular}


Table 2 Lung function data related to the duration of neonatal ventilation. Results are means and mean differences with $95 \%$ confidence intervals

\begin{tabular}{|c|c|c|c|c|}
\hline & $\begin{array}{l}\text { Airways } \\
\text { resistance } \\
\left(\mathrm{cm} \mathrm{H}_{2} \mathrm{O} / \mathrm{l} / \mathrm{sec}\right)\end{array}$ & $\begin{array}{l}\text { Functional } \\
\text { residual capacity } \\
\text { (ml/kg) }\end{array}$ & $\begin{array}{l}\text { Thoracic gas } \\
\text { volume } \\
(\mathrm{ml} / \mathrm{kg})\end{array}$ & $\begin{array}{l}\text { Specific } \\
\text { conductance } \\
\left(\sec ^{-1} / \mathrm{cm} \mathrm{H}_{2} \mathrm{O}\right)\end{array}$ \\
\hline $\begin{array}{l}\text { Group A } \\
\text { Group B } \\
\text { Group C } \\
\text { B-A } \\
\text { C-A }\end{array}$ & $\begin{array}{l}34 \cdot 00 \\
34 \cdot 07 \\
30 \cdot 43 \\
+0.07 \\
(-7 \cdot 35 \text { to }+7 \cdot 49) \\
-3 \cdot 57 \\
(-11 \cdot 48 \text { to }+4 \cdot 35)\end{array}$ & $\begin{array}{l}28.82 \\
27.62 \\
33.95 \\
-1.20 \\
(-5.73 \text { to }+3.33) \\
+5.13 \\
(-0.29 \text { to }+10.55)\end{array}$ & $\begin{array}{l}40.69 \\
36.23 \\
37.32 \\
-4.46 \\
(-10.55 \text { to }+1.62) \\
-3.38 \\
(-8.99 \text { to }+2.24)\end{array}$ & $\begin{array}{l}0.135 \\
0.148 \\
0.167 \\
+0.013 \\
(-0.031 \text { to }+0.056) \\
+0.032 \\
(-0.020 \text { to }+0.083)\end{array}$ \\
\hline
\end{tabular}

Table 3 Results of infants not ventilated in the neonatal period (group A)

\begin{tabular}{|c|c|c|c|c|c|c|c|c|}
\hline $\begin{array}{l}\text { Case } \\
\text { No }\end{array}$ & $\begin{array}{l}\text { Birth } \\
\text { weight } \\
\text { (g) }\end{array}$ & $\begin{array}{l}\text { Gestational } \\
\text { age } \\
\text { (weeks) }\end{array}$ & $\begin{array}{l}\text { Oxygen duration } \\
\text { in neonatal } \\
\text { period }\end{array}$ & $\begin{array}{l}\text { Weight } \\
\text { at time of } \\
\text { measurement } \\
(\mathrm{kg})\end{array}$ & $\begin{array}{l}\text { Airwagys } \\
\text { resistance } \\
\left(\mathrm{cm} \mathrm{H}_{2} \mathrm{O} / \mathrm{l} / \mathrm{sec}\right)\end{array}$ & $\begin{array}{l}\text { Functional } \\
\text { residual } \\
\text { capacity } \\
(\mathrm{ml} / \mathrm{kg})\end{array}$ & $\begin{array}{l}\text { Thoracic gas } \\
\text { volume } \\
\text { ( } \mathrm{ml} / \mathrm{kg} \text { ) }\end{array}$ & $\begin{array}{l}\text { Specific } \\
\text { conductance } \\
\left(\sec ^{-1} / \mathrm{cm} \mathrm{H}_{2} \mathrm{O}\right)\end{array}$ \\
\hline $\begin{array}{r}1 \\
2 \\
3 \\
4 \\
5 \\
6 \\
7 \\
8 \\
9 \\
10 \\
11 \\
12\end{array}$ & $\begin{array}{l}1312 \\
1440 \\
1426 \\
1346 \\
1270 \\
1780 \\
1800 \\
1640 \\
1320 \\
1100 \\
1210 \\
1500\end{array}$ & $\begin{array}{l}28 \\
28 \\
29 \\
28 \\
30 \\
32 \\
31 \\
31 \\
31 \\
28 \\
27 \\
30\end{array}$ & $\begin{array}{l}0 \\
10 \text { hours } \\
0 \\
1 \text { hour } \\
0 \\
4 \text { hours } \\
2.5 \text { days } \\
1 \text { day } \\
1.5 \text { days } \\
5 \text { days } \\
0 \\
0.5 \text { day }\end{array}$ & $\begin{array}{l}5 \cdot 60 \\
5 \cdot 40 \\
6 \cdot 48 \\
6 \cdot 35 \\
6 \cdot 42 \\
7 \cdot 28 \\
6 \cdot 80 \\
6 \cdot 00 \\
6 \cdot 85 \\
4 \cdot 20 \\
6 \cdot 60 \\
6 \cdot 15\end{array}$ & $\begin{array}{l}22 \cdot 0 \\
32 \cdot 0 \\
39 \cdot 0 \\
39 \cdot 0 \\
43 \cdot 0 \\
19 \cdot 0 \\
28 \cdot 0 \\
42 \cdot 0 \\
43 \cdot 0 \\
24 \cdot 0 \\
33 \cdot 0 \\
44 \cdot 0\end{array}$ & $\begin{array}{l}25 \cdot 5 \\
24 \cdot 4 \\
32 \cdot 3 \\
24 \cdot 3 \\
41 \cdot 4 \\
30 \cdot 0 \\
* \\
* \\
27 \cdot 0 \\
35 \cdot 0 \\
21 \cdot 7 \\
26 \cdot 6\end{array}$ & $\begin{array}{l}34 \cdot 3 \\
53 \cdot 7 \\
40 \cdot 1 \\
33 \cdot 5 \\
45 \cdot 2 \\
33 \cdot 0 \\
29 \cdot 7 \\
42 \cdot 7 \\
34 \cdot 5 \\
50 \cdot 0 \\
51 \cdot 0 \\
40.6\end{array}$ & $\begin{array}{l}0.237 \\
0.108 \\
0.099 \\
0.121 \\
0.080 \\
0.219 \\
0.177 \\
0.107 \\
0.099 \\
0.198 \\
0.089 \\
0.091\end{array}$ \\
\hline
\end{tabular}

*Results are not available.

Nesults are not available.
No infant was admitted to hospital during the first six months.

Table 4 Results of infants ventilated for less than seven days (group B)

\begin{tabular}{|c|c|c|c|c|c|c|c|c|c|c|}
\hline $\begin{array}{l}\text { Case } \\
\text { No }\end{array}$ & $\begin{array}{l}\text { Birth } \\
\text { weight } \\
\text { (g) }\end{array}$ & $\begin{array}{l}\text { Gestational } \\
\text { age } \\
\text { (weeks) }\end{array}$ & $\begin{array}{l}\text { Oxygen } \\
\text { duration } \\
\text { after IPPV } \\
\text { (days) }\end{array}$ & $\begin{array}{l}\text { Ventilation } \\
\text { (days) }\end{array}$ & $\begin{array}{l}\text { No of } \\
\text { admissions to } \\
\text { hospital (first } \\
\text { six months) }\end{array}$ & $\begin{array}{l}\text { Weight } \\
\text { at time of } \\
\text { measurement } \\
(\mathrm{kg})\end{array}$ & $\begin{array}{l}\text { Airways } \\
\text { resistance } \\
\left(\mathrm{cm} \mathrm{H}_{2} \mathrm{O} / \mathrm{l} / \mathrm{sec}\right)\end{array}$ & $\begin{array}{l}\text { Functional } \\
\text { residual } \\
\text { capacity } \\
(\mathrm{ml} / \mathrm{kg})\end{array}$ & $\begin{array}{l}\text { Thoracic } \\
\text { gas } \\
\text { volume } \\
(\mathrm{ml} / \mathrm{kg})\end{array}$ & $\begin{array}{l}\text { Specific } \\
\text { conductance } \\
\left(\mathrm{sec}^{-1} / \mathrm{cm}\right. \\
\left.\mathrm{H}_{2} \mathrm{O}\right)\end{array}$ \\
\hline 13 & 1900 & 34 & 2 & 5 & $\begin{array}{l}1 \\
\text { (viral infection) }\end{array}$ & 5.44 & $42 \cdot 0$ & $25 \cdot 5$ & $49 \cdot 0$ & 0.060 \\
\hline $\begin{array}{l}14 \\
15 \\
16 \\
17\end{array}$ & $\begin{array}{l}1170 \\
1200 \\
1210 \\
1180\end{array}$ & $\begin{array}{l}29 \\
28 \\
28 \\
27\end{array}$ & $\begin{array}{l}6 \\
1 \\
0.5 \\
1\end{array}$ & $\begin{array}{l}5 \\
2 \\
1 \\
3\end{array}$ & $\begin{array}{l}\bar{Z} \\
\frac{1}{1} \\
\text { (bronchiolitis) }\end{array}$ & $\begin{array}{l}6 \cdot 25 \\
5 \cdot 60 \\
7 \cdot 30 \\
7 \cdot 00\end{array}$ & $\begin{array}{l}49 \cdot 0 \\
50 \cdot 5 \\
25 \cdot 0 \\
23 \cdot 0\end{array}$ & $\begin{array}{l}26 \cdot 0 \\
27 \cdot 3 \\
24 \cdot 2 \\
26 \cdot 0\end{array}$ & $\begin{array}{l}46 \cdot 7 \\
45 \cdot 0 \\
29 \cdot 9 \\
30 \cdot 7\end{array}$ & $\begin{array}{l}0.060 \\
0.079 \\
0 \cdot 183 \\
0.202\end{array}$ \\
\hline $\begin{array}{l}18 \\
19 \\
20 \\
21 \\
22 \\
23\end{array}$ & $\begin{array}{r}876 \\
1274 \\
816 \\
1730 \\
1778 \\
516\end{array}$ & $\begin{array}{l}27 \\
32 \\
25 \\
32 \\
29 \\
29\end{array}$ & $\begin{array}{l}2 \\
1 \\
0.4 \\
1.5 \\
0 \cdot 1 \\
0 \cdot 1\end{array}$ & $\begin{array}{l}5 \\
4 \\
4 \\
3 \\
1 \cdot 3 \\
2\end{array}$ & $\begin{array}{l}= \\
= \\
\overline{-} \\
\text { (chest infection) }\end{array}$ & $\begin{array}{l}7 \cdot 50 \\
7 \cdot 05 \\
7 \cdot 55 \\
7 \cdot 03 \\
6.90 \\
4 \cdot 99\end{array}$ & $\begin{array}{l}28 \cdot 0 \\
27 \cdot 0 \\
23 \cdot 0 \\
25 \cdot 0 \\
40 \cdot 0 \\
33 \cdot 0\end{array}$ & $\begin{array}{l}26 \cdot 0 \\
25 \cdot 1 \\
30 \cdot 6 \\
28 \cdot 3 \\
28 \cdot 0 \\
37 \cdot 5\end{array}$ & $\begin{array}{l}33 \cdot 6 \\
32 \cdot 4 \\
40 \cdot 0 \\
53 \cdot 0 \\
28 \cdot 7 \\
46.9\end{array}$ & $\begin{array}{l}0 \cdot 142 \\
0 \cdot 163 \\
0 \cdot 144 \\
0 \cdot 108 \\
0 \cdot 126 \\
0 \cdot 129\end{array}$ \\
\hline $\begin{array}{l}24 \\
25 \\
26 \\
27 \\
28 \\
29 \\
30 \\
31 \\
32 \\
33 \\
34\end{array}$ & $\begin{array}{r}840 \\
1554 \\
1018 \\
996 \\
1300 \\
1430 \\
1070 \\
1279 \\
720 \\
1138 \\
1300\end{array}$ & $\begin{array}{l}26 \\
29 \\
28 \\
29 \\
33 \\
31 \\
28 \\
30 \\
27 \\
27 \\
29\end{array}$ & $\begin{array}{l}1 \\
0 \\
2 \\
1 \cdot 5 \\
2 \\
0 \cdot 1 \\
0 \cdot 2 \\
1 \cdot 5 \\
1 \cdot 5 \\
0 \cdot 8 \\
0\end{array}$ & $\begin{array}{l}2 \\
2 \\
6 \\
2 \cdot 5 \\
0 \cdot 5 \\
0 \cdot 5 \\
0.5 \\
0 \cdot 3 \\
0 \cdot 9 \\
0 \cdot 8 \\
0.3\end{array}$ & $\begin{array}{l}= \\
= \\
= \\
= \\
= \\
=\end{array}$ & $\begin{array}{l}4 \cdot 10 \\
6 \cdot 95 \\
6 \cdot 60 \\
5 \cdot 44 \\
5 \cdot 10 \\
6 \cdot 00 \\
7 \cdot 46 \\
6 \cdot 90 \\
5 \cdot 58 \\
5 \cdot 10 \\
7 \cdot 60\end{array}$ & $\begin{array}{l}22 \cdot 0 \\
52 \cdot 0 \\
52 \cdot 0 \\
25 \cdot 0 \\
45 \cdot 0 \\
27 \cdot 1 \\
31 \cdot 0 \\
31 \cdot 0 \\
28 \cdot 0 \\
46 \cdot 0 \\
25 \cdot 0\end{array}$ & $\begin{array}{l}28 \cdot 9 \\
23 \cdot 7 \\
28 \cdot 0 \\
23 \cdot 5 \\
38 \cdot 5 \\
18 \cdot 3 \\
20 \cdot 0 \\
41 \cdot 0 \\
31 \cdot 5 \\
27 \cdot 4 \\
30 \cdot 4\end{array}$ & $\begin{array}{l}39 \cdot 0 \\
25 \cdot 0 \\
28 \cdot 3 \\
25 \cdot 5 \\
42 \cdot 9 \\
34 \cdot 3 \\
31 \cdot 5 \\
45 \cdot 6 \\
32 \cdot 2 \\
27 \cdot 8 \\
29 \cdot 3\end{array}$ & $\begin{array}{l}0 \cdot 284 \\
0 \cdot 111 \\
0 \cdot 104 \\
0 \cdot 288 \\
0 \cdot 101 \\
0 \cdot 202 \\
0 \cdot 137 \\
0 \cdot 102 \\
0 \cdot 198 \\
0 \cdot 153 \\
0 \cdot 179\end{array}$ \\
\hline
\end{tabular}

Table 5 Results of infants ventilated for more than seven days (group $C$ )

\begin{tabular}{|c|c|c|c|c|c|c|c|c|c|c|}
\hline $\begin{array}{l}\text { Case } \\
\text { No }\end{array}$ & $\begin{array}{l}\text { Birth } \\
\text { weight } \\
\text { (g) }\end{array}$ & $\begin{array}{l}\text { Gestational } \\
\text { age } \\
\text { (weeks) }\end{array}$ & $\begin{array}{l}\text { Oxygen } \\
\text { duration } \\
\text { after IPPV } \\
\text { (days) }\end{array}$ & $\begin{array}{l}\text { Ventilation } \\
\text { (days) }\end{array}$ & $\begin{array}{l}\text { No of } \\
\text { admissions to } \\
\text { hospital (first } \\
\text { six months) }\end{array}$ & $\begin{array}{l}\text { Weight } \\
\text { at time of } \\
\text { measurement } \\
(\mathrm{kg})\end{array}$ & $\begin{array}{l}\text { Airways } \\
\text { resistance } \\
\left(\mathrm{cm} \mathrm{H}_{2} \mathrm{O} / / \mathrm{sec}\right)\end{array}$ & $\begin{array}{l}\text { Functional } \\
\text { residual } \\
\text { capacity } \\
(\mathrm{ml} / \mathrm{kg})\end{array}$ & $\begin{array}{l}\text { Thoracic } \\
\text { gas } \\
\text { volume } \\
(\mathrm{mll} / \mathrm{kg})\end{array}$ & $\begin{array}{l}\text { Specific } \\
\text { conductance } \\
\left(\mathrm{sec}^{-1} / \mathrm{cm}\right. \\
\left.\mathrm{H}_{2} \mathrm{O}\right)\end{array}$ \\
\hline 35 & 810 & 26 & 6 & 11 & 1 & 3.80 & $28 \cdot 0$ & $37 \cdot 0$ & $44 \cdot 5$ & 0.121 \\
\hline $\begin{array}{l}36^{*} \\
37\end{array}$ & $\begin{array}{l}886 \\
685\end{array}$ & $\begin{array}{l}26 \\
24\end{array}$ & $\begin{array}{r}36 \\
6\end{array}$ & $\begin{array}{l}42 \\
14\end{array}$ & $\frac{\text { (chest infection) }}{1}$ & $\begin{array}{l}5 \cdot 40 \\
4 \cdot 73\end{array}$ & $\begin{array}{l}21 \cdot 0 \\
36 \cdot 0\end{array}$ & $\begin{array}{l}34 \cdot 6 \\
34 \cdot 1\end{array}$ & $\begin{array}{l}37 \cdot 6 \\
36 \cdot 6\end{array}$ & $\begin{array}{l}0 \cdot 160 \\
0 \cdot 113\end{array}$ \\
\hline 38 & 1074 & 28 & 4 & 11 & (chest infection) & $5 \cdot 10$ & 23.0 & $25 \cdot 5$ & $41 \cdot 2$ & 0.153 \\
\hline $\begin{array}{l}39 \\
40 \\
41^{*}\end{array}$ & $\begin{array}{r}1120 \\
1468 \\
506\end{array}$ & $\begin{array}{l}27 \\
32 \\
23\end{array}$ & $\begin{array}{l}2 \\
2 \\
6\end{array}$ & $\begin{array}{r}8 \\
8 \\
28\end{array}$ & $\frac{-}{1}$ & $\begin{array}{l}6 \cdot 30 \\
6 \cdot 17 \\
3 \cdot 75\end{array}$ & $\begin{array}{l}26 \cdot 0 \\
30 \cdot 0 \\
24 \cdot 0\end{array}$ & $\begin{array}{l}36 \cdot 0 \\
39 \cdot 2 \\
27 \cdot 0\end{array}$ & $\begin{array}{l}35 \cdot 8 \\
39 \cdot 2 \\
41 \cdot 0\end{array}$ & $\begin{array}{l}0 \cdot 170 \\
0 \cdot 138 \\
0 \cdot 271\end{array}$ \\
\hline $\begin{array}{l}42^{*} \\
43^{*} \\
44 \\
45\end{array}$ & $\begin{array}{r}1444 \\
1512 \\
1092 \\
682\end{array}$ & $\begin{array}{l}27 \\
29 \\
30 \\
24\end{array}$ & $\begin{array}{r}11 \\
5 \\
5 \\
2\end{array}$ & $\begin{array}{c}20 \\
23 \\
8 \cdot 5 \\
10\end{array}$ & $\begin{array}{l}- \\
\overline{1} \\
\text { (febrile } \\
\text { convulsion) }\end{array}$ & $\begin{array}{l}6 \cdot 27 \\
6 \cdot 12 \\
3.94 \\
6 \cdot 20\end{array}$ & $\begin{array}{l}19 \cdot 2 \\
27 \cdot 0 \\
45 \cdot 0 \\
35 \cdot 0\end{array}$ & $\begin{array}{l}22 \cdot 8 \\
40 \cdot 8 \\
41 \\
32 \cdot 1\end{array}$ & $\begin{array}{l}25 \cdot 3 \\
40 \cdot 0 \\
39 \cdot 1 \\
35 \cdot 1\end{array}$ & $\begin{array}{l}0 \cdot 328 \\
0 \cdot 160 \\
0 \cdot 144 \\
0 \cdot 130\end{array}$ \\
\hline 46 & 836 & 29 & 3 & 9 & $\begin{array}{l}1 \\
\text { (bronchiolitis) }\end{array}$ & 5.25 & $51 \cdot 0$ & $33 \cdot 5$ & $32 \cdot 4$ & 0.115 \\
\hline
\end{tabular}


between the three groups of infants regardless of the duration of neonatal ventilation (tables 2 , 3,4 , and 5 ). The $95 \%$ confidence intervals of the difference of the means of groups $A(34 \mathrm{~cm}$ $\left.\mathrm{H}_{2} \mathrm{O} / \mathrm{l} / \mathrm{sec}\right)$ and $\mathrm{B}\left(34 \cdot 1 \mathrm{~cm} \mathrm{H} \mathrm{H}_{2} \mathrm{O} / \mathrm{sec}\right)$ are $-6 \cdot 49$ to $6.73 \mathrm{~cm} \mathrm{H} \mathrm{H}_{2} \mathrm{O} / \mathrm{l} / \mathrm{sec}$ and between groups $\mathrm{A}$ ( 34 $\left.\mathrm{cm} \mathrm{H}_{2} \mathrm{O} / 1 / \mathrm{sec}\right)$ and $\mathrm{C}\left(30.4 \mathrm{~cm} \mathrm{H}_{2} \mathrm{O} / 1 / \mathrm{sec}\right)$ are -3.8 to $11.0 \mathrm{~cm} \mathrm{H}_{2} \mathrm{O} / \mathrm{l} / \mathrm{sec}$.

\section{Discussion}

We report lung function measurements of infants of 6 months of age, rather than those of school age or older, as we thought it important to audit current ventilation practices. Our results could therefore be used, if important abnormalities were demonstrated, to influence that current practice. We investigated very preterm infants and compared our results with those in earlier reports. Our study audits a complete cohort of such preterm infants excluding only those with bronchopulmonary dysplasia who were oxygen dependent at 6 months of age. Our study population were ventilated using modern ventilators by high frequency positive pressure ventilation (IPPV). In this cohort we have been able to report a number of indices of lung function, thoracic gas volume, airways resistance, and functional residual capacity.

Airways resistance measurements in the $\mathbf{4 6}$ infants included in the present study showed a slightly greater interindividual variability (SD $9.5 \mathrm{~cm} \mathrm{H} \mathrm{H}_{2} \mathrm{O} / 1 / \mathrm{sec}$ ) than we had demonstrated in a previous group of 20 consecutive preterm of infants, whose data we used to calculate the trial size. As the increase in variability was only small our trial size remained appropriate. Enrolling 12 patients in each group still gave us $75 \%$ power at the $5 \%$ level to detect a difference in resistance of $10 \mathrm{~cm} \mathrm{H} \mathrm{H}_{2} \mathrm{O} / 1 / \mathrm{sec}$ between groups and $85 \%$ power at the $5 \%$ level to detect a difference of $12 \mathrm{~cm} \mathrm{H} \mathrm{O} / 1 / \mathrm{sec}$.

In the present study we have not included a control group as it was felt unjustifiable to sedate healthy 6 month old infants to perform plethysmographic measurements to establish a normal range. Indeed, one may also query if such infants' results would be appropriate to use as a reference range for comparison with the results of a very preterm population. Many published reference ranges relate only to term infants or a mixture of preterm and term infants. ${ }^{19}$ As a consequence functional residual capacity, measured by dilution methods, is reported to vary from $21.5 \mathrm{ml} / \mathrm{kg}$ to $37 \mathrm{ml} / \mathrm{kg}$. ${ }^{19}$ The mean data of the present study fall within this wide range. For each measurement there was a wide scatter of results. This may reflect differences in our patients regarding their gestation at birth and severity of their respiratory illness.

We have not demonstrated a significant difference in functional residual capacity, thoracic gas volume, or airways resistance in infants ventilated for different lengths of time nor between ventilated and non-ventilated infants. Our measurements of thoracic gas volume are very similar to those of Stocks and Godfrey ${ }^{12}$ and previously published reference ranges. ${ }^{20} 21$ Our airways resistance results in all three groups of infants were similar to Stocks and Godfrey's ventilated infants but higher than their nonventilated infants and the published reference range. ${ }^{20}$ Our technique of measurement and its reproducibility was very similar to that used previously, ${ }^{12}$ and the number of patients we enrolled was twice that included in the earlier study. ${ }^{12}$ We therefore think that we are reporting a true difference in the findings of the two studies. The high airways resistance of all our three groups and the failure to demonstrate a difference in airways resistance between the groups, regardless of the need for neonatal ventilation, may be explained by the immaturity of the patients we examined. ${ }^{12}$ Two other recent reports have failed to confirm an association between neonatal ventilation and lung function abnormalities. ${ }^{22} 23$ Both groups reported that poor airway function at school age was independent of neonatal respiratory illness and closely associated with low birth weight. ${ }^{22}{ }^{23}$ Further evidence to support this association was our finding of abnormal airways resistance in a group of four infants who, although requiring no form of respiratory support in the neonatal period, had been born very preterm between 27 and 30 weeks of gestational age.

Plethysomography cannot be performed on oxygen dependent infants thus, in this study, infants with severe bronchopulmonary dysplasia had to be excluded. Our results cannot therefore represent a complete audit of neonatal ventilation. All five infants with severe bronchopulmonary dysplasia excluded from our study were born before 26 weeks completed gestation and had many complications such as patent ductus arteriosus, infection, and pulmonary air leak. Until a much larger group of these infants can be collected and studied it will not be possible to determine the contribution of a single factor such as neonatal ventilation in the pathogenesis of severe chronic lung damage. All other infants, however, consecutively cared for on our unit, were included in this study. The similarity of results from our non-ventilated and ventilated infants and lack of difference in airways resistance regardless of the duration of ventilation suggests that factors other than neonatal ventilation may be more important in the pathogenesis of chronic lung function abnormalities.

Dr B Yuksel (research fellow) is supported by the Joint Research Council. The equipment for this study was generously provided by Children Nationwide Medical Research Fund.

1 Edwards DK, Dyer WM, Northway WH Jr. Twelve years' experience with bronchopulmonary dysplasia. Pediatrics 1977;59:839-46.

2 Hodson WA, Truog WE, Mayock DE, Lyrene R, Woodrum DE. Bronchopulmonary dysplasia: the need for epidemiologic studies. I Pediatr 1979;95:848-51.

3 Sauve RS, Singhal N. Long term morbidity of infants with bronchopulmonary dysplasia. Pediatrics 1985;76:725-33.

4 Bowman $\mathrm{E}, \mathrm{Yu} \mathrm{V}$. Continuing morbidity in extremely low birthweight infants. Early Hum Dev 1989;18:165-74.

5 Greenough A, Maconochie I, Gamsu HR. Do respiratory problems cease when preterm babies leave neonatal intensive care? European Respiratory Joumal 1988;1(suppl 2): 227A

6 Bryan MH, Hardie MJ, Reilly BJ, et al. Pulmonary function studies during the first year of life in infants recovering from the respiratory distress syndrome. Pediatrics 1973;52: 169-78.

7 Gerhardt T, Tobia JL, Goldman SL, et al. Serial lung function measurements with chronic lung disease. Pediatr Res 1983;17:376A. 
8 Rhodes PG, Graves GR, Patel OM, et al. Minimizing pneumothorax and bronchopulmonary dysplasia in ventilated infants with hyaline membrane disease. $\mathcal{f}$ Pediat 1983;103:634-7.

9 Tooley WH. Epidemiology of bronchopulmonary dysplasia. f Pediatr 1979;95:851-5.

10 Barnes ND, Glover WJ, Hull D, Milner AD. Effects of prolonged positive pressure ventilation in infancy. Lance 1969;ii:1096-9.

11 Taghizadeh A, Reynolds EOR. Pathogenesis of bronchopulmonary dysplasia following hyaline membrane disease. $A m$ f Pathol 1976;82:241-54.

12 Stocks J, Godfrey S. The role of artificial ventilation, oxygen and CPAP in the pathogenesis of lung damage in neonates: assessment by serial measurements of lung function. Pediatrics 1976;57:352-62.

13 Greenough A, Pool J, Greenall F, Morley C, Gamsu H. Comparison of different rates of artificial ventilation in preterm neonates with the respiratory distress syndrome. preterm neonates with the respiratory
Acta Paediatr Scand 1987;76:706-12.

14 Greenough A, Greenall F. Patient triggered ventilation in premature neonates. Arch Dis Child 1988;63:77-8.

15 Greenough A, Pool JB. Neoanatal patient triggered ventila tion. Arch Dis Child 1988;63:394-7.

16 Greenough A, Greenall F. Performance of respirators at fast rates commonly used in neonatal intensive care units. Pediatr Pulmonol 1987;3:357-61.

17 Dubois AB, Botelho SY, Bedell GN, et al. A rapid plethysmographic method for measuring thoracic gas volume: a comparison with nitrogen washout method for measuring functional residual capacity in normal subjects. $\mathcal{F}$ Clin Invest 1956;35:322-6.

18 Dubois AB, Botelho SY, Comroe JH. A new method for measuring airway resistance in man using a body plethy smograph: values in normal subjects and in patients with respiratory disease. f Clin Invest 1956;35:327-35.

19 Quanjer PH, Stocks J, Polgar G, Wise M, Karlberg J, Borsboom G. Compilation of reference values for lung function measurements in children. European Respiratory Joumal 1989;2(suppl 4):184s-261s.

20 Radford M. Measurement of airway resistance and thoracic gas volume in infancy. Arch Dis Child 1974;49:611-5.

21 Phelan PD, Williams HE. Ventilatory studies in healthy infants. Pediatr Res 1969;3:425-32.

22 Mansell AL, Driscoll JM, James LS. Pulmonary follow-up of Mansell AL, Driscoll JM, James LS. Pulmonary follow-up of
moderately low birthweight infants with and without

23 Chan KN, Nobel-Jamieson CM, Elliman A, Bryan EM Silverman $M$. Lung function in children of low birth Silverman M. Lung function in childre
weight. Arch Dis Child 1989;64:1284-93.

\section{Hyperactivity}

Article number 3861d of the Archivist Transatlantic Guide runs as follows: "doctors who say "tom-ay-toe" frequently diagnose hyperactivity whilst those who say "tom-ar-toe" rarely do'. This basic rule of medical conduct has never, to my mind, been explained very convincingly on the basis of attitudinal and psychosocial differences between the two nations. Most British paediatricians take in such facts as that $6 \%$ of all children in Baltimore County are given stimulant drugs for hyperactivity ${ }^{1}$ with more than a touch of incredulity, not to say apprehension. Pathogenesis, too, tends to be viewed differently, more emphasis being given to biological factors in America and to psychosocial determinants in Britain.

Recent work at the National Institutes of Health in Bethesda (Zametkin et al, New England Fournal of Medicine, 1990; 323:1361-6) will have revived interest in biological mechanisms. Using positron emission tomography cerebral glucose metabolism was studied in 50 normal adults and in 25 adults who had been diagnosed as hyperactive in childhood, still had symptoms, and had hyperactive children. A significant reduction in overall cerebral glucose metabolism was found in the hyperactive subjects and the reduction was greatest in the premotor cortex and the superior prefrontal cortex, areas of the brain known to be concerned with control of attention and motor activity.

A symptom such as hyperactivity is bound to be multifactorial in its origins. People who are still hyperactive as adults and who also have hyperactive children are obviously a select group, but the demonstration of changed cerebral glucose metabolism is of great interest. It is not known whether these changes are primary or secondary or whether they occur in children as well as in adults. Neither is it known whether drug treatment would reverse the changes. Clearly there is much to elucidate but it seems a promising path to follow.

\section{ARCHIVIST}

1 Weiss G. Hyperactivity in childhood. N Engl $\mathcal{J}$ Med 1990;323:1413-5. 